ISCKMC 2020

International Scientific Congress «KNOWLEDGE, MAN AND CIVILIZATION»

\title{
ANALYSIS OF PRELIMINARY POSITION OF ARBITRATION REGARDING THE AZOV-KERCH WATER AREA
}

\author{
Elena Chuklina (a)* \\ *Corresponding author \\ (a) Federal Research Centre the Southern Scientific Centre of The Russian Academy of Sciences, 41, Chekhov St., \\ Rostov-on-Don, Russia, die_sehnsucht@mail.ru
}

\begin{abstract}
The article shows the results of preliminary hearing in the case of violation of the rights of the coastal state to use the Azov-Kerch water area, initiated by Ukraine in 2016 against the Russian Federation. In the absence of a joint statement of the parties on the choice of the judicial authority, the dispute was referred to Arbitration in accordance with Annex VII of the 1982 Convention on the Law of the Sea (UNCLOS). In the Memorandum forwarded, Ukraine claims that Russia violates the freedom of navigation of Ukrainian and foreign vessels, displaces fishermen from the zones occupied by them for a long period, impedes the production of gas and oil, and also refuses to return Ukrainian oil rigs. In defence, Russia asks to reject all of Ukraine's claims due to the lack of competence of the Arbitration to resolve issues related to the exercise by Russia of its sovereign rights in coastal waters. The author of the article examines the position of the Arbitration expressed in relation to each argument of Russia, including arguments about the lack of jurisdiction over disputes related to military activities. The importance of recognition by the Arbitration of the absence of jurisdiction, directly or indirectly, to consider disputes related to sovereignty over Crimea is emphasized. At the same time the Arbitration ruled to study the implementation of the internal waters regime in practice during the trial, as well as to verify the reliability of the historical title to which Russia refers.
\end{abstract}

2357-1330 @ 2021 Published by European Publisher.

Keywords: Sea of Azov, Kerch Strait, Arbitration, maritime law

EY NC ND This is an Open Access article distributed under the terms of the Creative Commons Attribution-Noncommercial 4.0 Unported License, permitting all non-commercial use, distribution, and reproduction in any medium, provided the original work is properly cited. 


\section{Introduction}

The Sea of Azov plays an important role for the development of industrial fishing, recreation, energy production, as well as transportation and economics due to its exit to the Black Sea through the Kerch Strait. A retrospective view shows that until 1991 the Sea of Azov was de-jure and de-facto the internal sea of one state: first the Russian Empire, and then the Soviet Union (Matishov, 2019). The problems of determining the legal status of the Sea of Azov and the delimitation of its borders arose after the collapse of the USSR with the emergence of two independent states pursuing their own interests. The negotiations between Russia and Ukraine were difficult and lengthy. Only in 2003 it was possible to conclude an Agreement between the Russian Federation and Ukraine on cooperation in the use of the Sea of Azov and the Kerch Strait. From 2005 to 2012 the Ukrainian and Russian delegations negotiated the delimitation of the Azov-Kerch water area. However, the events of 2014, which changed the relations between the countries for the worse 'froze' the agreements reached on the delimitation of the sea.

\section{Problem Statement}

On 16 September 2016, Ukraine submitted to the Russian Federation a notice and a statement of claim regarding a dispute concerning the rights of the coastal states in the Black Sea, the Sea of Azov and the Kerch Strait. Since Russia and Ukraine have not specifically stated in which court the disputes arising over the Azov-Kerch water area should be considered, in accordance with the Article 287 of UNCLOS the dispute was referred to Arbitration. In its preliminary objections, Russia stated that the Arbitration had no jurisdiction over all of Ukraine's claims. However, the Arbitration Court dismissed some of the objections and decided to clarify the requirements of the Ukrainian side.

\section{Research Questions}

In this regard, it seems necessary to analyze the following materials in response to the preliminary hearing:

1. Russia's preliminary objections to Ukraine's claims;

2. Position of the Arbitration Tribunal on the arguments of the Ukrainian and Russian delegations.

\section{Purpose of the Study}

The purpose of the article is to present the position of the international court in relation to the existing agreements and disagreements between Russia and Ukraine on the legal status and legal regime of the Sea of Azov and the Kerch Strait. It can be assumed that the result of the consideration of the case will significantly affect the regulation of the joint use of the Azov-Kerch water area.

\section{Research Methods}

The main method used in this study is the formal legal analysis of international agreements and documents adopted at the preliminary stage of consideration of the case of Ukraine against Russia. 


\section{Findings}

It should be said that in 2009 Ukraine uttered threat to appeal to an international tribunal, when, at the third round of delimitation negotiations, representatives of the Ukrainian delegation demanded to review the status of the Azov-Kerch water area and divide it into zones in accordance with UNCLOS (RIA NEWS, 2009). Therefore, the Ukraine's initiation of a case in the Arbitration should not be considered an unpredictable and unexpected event.

Ukraine accused the Russian Federation of violating the provisions of UNCLOS and put forward the following claims: 1) restriction of access to oil and gas, which lie under the Ukrainian part of the water area; 2) cancellation of licenses issued by the government of Ukraine for energy production and issuance of licenses to Russian companies; 3) displacement of Ukrainian fishermen from the areas where they usually worked, which led to a sharp decline in the annual catch in Ukraine; 4) detention and pursuit of Ukrainian ships; 5) construction of a bridge across the Kerch Strait without approval (Opening Statement of Ukraine Transcript, 2019).

In its preliminary objections Russia stated that the Arbitration had no jurisdiction to consider the claim of Ukraine, substantiating its position as follows: First, Ukraine's claims primarily relate to Russia's exercise of its rights as a coastal state in the waters adjacent to the Crimean peninsula. Arbitration does not have jurisdiction to decide on the state ownership of the land territory, and specifically the Crimean peninsula.

Second, according to UNCLOS Annex VII, countries choose a special Arbitration to resolve disputes related to fishing, shipping, protection and preservation of the marine environment. Third, Russia announced that it excluded the jurisdiction of the Arbitration with respect to military activities and law enforcement activities due to the fact that, upon ratification of UNCLOS, procedures regarding disputes over military activities and security in sovereign zones were not adopted.

Finally, Russian representatives are convinced that, based on the Azov-Kerch Cooperation Treaty and the 2003 State Border Treaty, disputes between Russia and Ukraine over the adjacent sea areas and the Kerch Strait should be resolved exclusively through negotiations. Ukraine ignored the importance of negotiations and "thus failed to comply with the necessary procedural requirements before referring these matters to the Tribunal" (Preliminary Objections of the Russian Federation, 2019, par. 11).

One of the main decisions of the Arbitration is the refusal to directly or indirectly consider the issue of sovereignty over the Crimean peninsula. Since international maritime law does not provide clear guidance on the ability of ships established in accordance with UNCLOS to resolve issues related to sovereignty over land, in each case, the court must make an informed decision on its own (Volterra et al., 2018). In this situation, the Arbitration preferred not to interfere with the issue of the legitimacy of the state ownership of Crimea, thereby neutralizing the political component of the case.

At the same time, the Arbitration rejected the rest of the objections of the Russian side and decided to consider the claimed claims of Ukraine on the merits after clarifying them (Award on Preliminary Objections, 2020). Thus, the Arbitration considers that not any activity involving the use of warships or aircraft should be considered military activity, in respect of which the UNCLOS procedures are not applicable. This can be, for example, ensuring the protection of gas production. Proceeding from the fact that there is no clear delineation of the sea zones in the Azov-Kerch water area, the Arbitration considers 
it necessary to first find out whether the maritime rights of the parties overlap. Only after this issue has been resolved, the Arbitration Tribunal would decide on the absence or sufficiency of its jurisdiction over Ukraine's claims on obstruction of fishing and shipping.

The Arbitration also interpreted the provisions of the 2003 Russian-Ukrainian Treaties on the settlement of disputes in its own way, noting that "any peaceful/amicable" methods do not exclude an appeal to Arbitration in accordance with Annex VII of UNCLOS.

It should be noted that the Arbitration casts doubt on the regime of the internal waters of the Azov Sea and the Kerch Strait and the historical title that Russia refers to in support of this regime. This position may be due to Ukraine's statements at the preliminary hearing that the 2003 Treaty was concluded under pressure from the Russian Federation and in order to avoid a military conflict due to Russia's attempt to build a dam to Tuzla Island. The arbitration plans to find out whether there was a historical title for the Sea of Azov and the Kerch Strait in general and in the period after 1991, in particular, what legal regime was applied in this case.

For example, in the practice of the International Court of Justice, for the recognition of a historical title, as a rule, it is required to establish two facts: 1) continuous exercise by the state of its rights over a long period of time (Sokolova, 2014); 2) patient attitude, lack of protests from other countries /tacit consent, and tacit recognition (Romashev, 2018).

Most likely, these circumstances will be established by the Arbitration when considering the case.

The Arbitration also considers it necessary to study the Agreements concluded after 2003 in the field of navigation, exploitation of natural resources and protection of the marine environment, as well as maritime practice, including attitude towards third countries. A similar situation in the law of the sea is usually called disaggregation of a dispute, when one large claim is divided into several separate ones for the purpose of a comprehensive consideration of the case (Hill-Cawthorne, 2019).

In our opinion, an important point to which the attention should be paid is the validity of the AzovKerch Treaty of 2003, although Ukraine could terminate it after the termination of the Treaty of Friendship, Cooperation and Partnership between the Russian Federation and Ukraine in 1997. Obviously, that it is unprofitable for Ukraine to change the legal status and regime of the Sea of Azov, since the regime of internal waters gives it enough maritime rights and freedoms, even in the situation of aggravated political relations. In the event that the 2003 Treaty is denounced and UNCLOS extends to the Azov-Kerch water area, the maritime rights of Ukraine will inevitably be limited in accordance with the length of the coastal territories.

\section{Conclusion}

Thus, the preliminary stage of the consideration of the case of Ukraine against Russia ended with the adoption of a number of important decisions. Firstly, the Arbitration Court refused in any way to touch upon the issue of the state ownership of the Crimean peninsula, thereby not justifying Ukraine's hopes of supporting its position on Crimea at the level of an international judicial act. Secondly, the Arbitration will study the implementation of the internal waters regime established by the 2003 Treaty in practice and check the historical legal foundations to which Russia refers. The conclusions of the Arbitration can help to eliminate contradictions and unresolved issues regarding the legal status and 
regime of the Azov-Kerch water area, repeatedly raised by experts and scientists. Finally, the very fact of litigation can contribute to the search for an optimal model of relations in the field of joint use of the Azov-Kerch water area, when priority will be given to economic and security interests.

\section{Acknowledgments}

The study was carried out within the framework of the RFBR project No. 18-05-80043.

\section{References}

Award on Preliminary Objections. (2020). PCA Case no. 2017-06. https://pcacases.com/web/sendAttach/9272

Hill-Cawthorne, L. (2019). International Litigation and the Disaggregation of Disputes: Ukraine/Russia as a Case Study. Int. and Comparat. Law Quarterly, 68(4), 779-815.

Matishov, G. G. (2019). Atlas of geostrategic confrontations in the Kerch-Azov region. Publ. house of the SSC RAS

Opening Statement of Ukraine Transcript (2019). PCA Case no. 2017-06. https://pcacases.com/web/sendAttach/2678

Preliminary Objections of the Russian Federation (2019). PCA Case no. 2017-06. https://pcacases.com/web/sendAttach/2617

Romashev, Yu. S. (2018). Acceptance of practice as law (opinio juris) in the formation of international custom. Law. J. of the Higher School of Econ., 1, 124-148

Sokolova, E. L. (2014). Institute of Historical Waters in Contemporary International Law (Doctoral dissertation). Moscow.

RIA NEWS (2009). Ukraine may apply to a UN court to delimit borders with Russia. https://ria.ru/20090204/160964493.html

Volterra, R., Mandelli, G., \& Nistal, A. (2018). The Characterisation of the Dispute Concerning Coastal State Rights in the Black Sea, Sea of Azov and Kerch Strait. The Int. J. of Marine and Coastal Law, 33(3), 614-622 